\title{
Bunium persicum (Boiss.) B. Fedtsch: An overview on Phytochemistry, Therapeutic uses and its application in the food industry
}

\author{
Hassan Hassanzadazar ${ }^{*}$, Borzoo Taami ${ }^{1}$, Majid Aminzare ${ }^{1}$, Shahrzad Daneshamooz ${ }^{2}$ \\ ${ }^{1}$ Department of Food Safety and Hygiene, School of Public Health, Zanjan University of Medical Sciences, Zanjan, Iran. \\ ${ }^{2}$ Department of Microbiology, Zanjan University of Medical Sciences, Zanjan, Iran.
}

\begin{tabular}{|c|c|}
\hline ARTICLE INFO & ABSTRACT \\
\hline $\begin{array}{l}\text { Article history: } \\
\text { Received on: } 04 / 05 / 2018 \\
\text { Accepted on: } 16 / 08 / 2018 \\
\text { Available online: } 31 / 10 / 2018\end{array}$ & $\begin{array}{l}\text { Bunium persicum (Boiss.) B. Fedtsch as a plant of the Apiaceae family grows in different regions of Asia such as } \\
\text { Central Asia, Iran, Pakistan, Afghanistan, and India. This plant has significant medicinal, antimicrobial and antioxidant } \\
\text { properties which indicate its high potential for use in the medicine and food industry. In traditional medicine, it is } \\
\text { used to treat or improve some cases such as digestive and urinary disorders, diabetes, obesity and increasing breast } \\
\text { milk. A comprehensive literature review was conducted by searching studies in all relevant authentic scientific }\end{array}$ \\
\hline $\begin{array}{l}\text { Key words: } \\
\text { Antimicrobial effect, } \\
\text { Antioxidant effect, Bunium } \\
\text { persicum, Phytochemistry, } \\
\text { Therapeutic effects. }\end{array}$ & $\begin{array}{l}\text { Carum carvi, Persian Cumin, Zire kuhi, Shah zira, Kala Zeera, Jira, Wild caraway and wild cumin without limitation } \\
\text { up to } 10 \text { November } 2017 \text {. According to researches, this plant and its derivatives are valuable compounds that have } \\
\text { antimicrobial, antioxidant, anti-inflammatory, anti-diabetes, antihyperlipid and analgesic properties. Bunium persicum } \\
\text { essential oil contains high levels of oxygenated monoterpenes, especially } \gamma \text {-Terpinene, cuminaldehyde, } \rho \text {-cymene and } \\
\text { limonene, which has high antimicrobial and antioxidant effects. Due to the fact that Bunium persicum is widely used } \\
\text { in people's diet as a flavoring agent, there is no major concern about the toxic effects of this plant. }\end{array}$ \\
\hline
\end{tabular}

\section{INTRODUCTION}

Bunium persicum (Boiss.) B. Fedtsch is a plant of Apiaceae family called wild caraway. It is a perennial aromatic plant with small white or pink flowers and small brown beans growing wild in areas with Mediterranean climate such as central and western Asia including Iran, Turkey, Syria, Pakistan, Tajikistan, Afghanistan, North India (Kashmir and Pamir), China, some parts of Europe, Northern Africa and South America (Aminzare et al., 2017a; Miraj and Kiani, 2016; Salehi et al., 2008). This plant is called with different names throughout the world as "Great pignut", "Black zire"," Black caraway", "Carum carvi", "Persian Cumin", "Zire kuhi”, "Shah zira ",, Kala Zeera”, "Jira”, "Wild caraway" and "wild cumin". B. Persicum (BP) has small $(30 \mathrm{~cm})$ to tall $(80 \mathrm{~cm})$ varieties which squeezed or expanded with large or small branches (Figure 1a) (Mandegari et al., 2012; Sofi

\footnotetext{
${ }^{*}$ Corresponding Author

Hassan Hassanzadazar, DVM, PhD, Department of Food Safety and

Hygiene, School of Public Health, Zanjan University of Medical

Sciences, Zanjan, Iran.E-mail: hassanzadazar_h@zums.ac.ir
}

et al., 2009). Seeds of the plant are brown or dark brown called Zireh kuhi in Iran meaning wild cumin (Figure 1b) (Iacobellis et al., 2005). 1000 seeds of this plant weigh about 2 grams (Sofi et al., 2009). Phytochemical profile of Bunium persicum (Boiss.) B. Fedtsch has shown flavonoids, phenolic acids, and aldehydes as well as a high content of mono-terpenes and sesquiterpenes contained in the essential oil and extracts of this plant (Chizzola et al., 2014).

In recent years, application of natural compounds particularly medicinal plants has increased in food due to their potential to increase the food safety and shelf life (Iacobellis et al., 2005). B. persicum (BP) is used for culinary intentions as a spice and flavoring agent in foods and beverages such as bread cooking, rice, yoghurt, cheese and in confectionery products. It has a strong earthy aroma is sharpened by frying and cooking it (Aminzare et al., 2017a; Sharififar et al., 2010; Sofi et al., 2009). This plant is also used in the perfume and cosmetics (Salehi et al., 2008).

There are several reports of therapeutic and functional properties of this plant. Seeds of this plant are mainly considered 
as a carminative and as well as an astringent for treating diarrhea (Sofi et al., 2009). Several therapeutic effects are explained for this plant in traditional and modern medicine. B. persicum is used for treating gastrointestinal and urinary disorders such as stomatitis stimulant, flatulent indigestion, dyspeptic headache, relieve of heartburn, colic, and diarrhea as well as dyspepsia, hysteria and for improving liver function and obesity. It is used as an anticonvulsant, anti-diabetic, anti-asthma, antispasmodic, antiepileptic, anti-obstruction, diuretic and flow increaser of breast milk (Miraj and Kiani, 2016). It also exhibits good antiinflammatory activity and anti-oxidative, free radicals scavenging, antimicrobial and anti-parasitic effects have been reported for this plant (Agah et al., 2013; Mandegary et al., 2012). This study was conducted to review and explain the biological and medicinal properties of BP and its effects on food preservation.
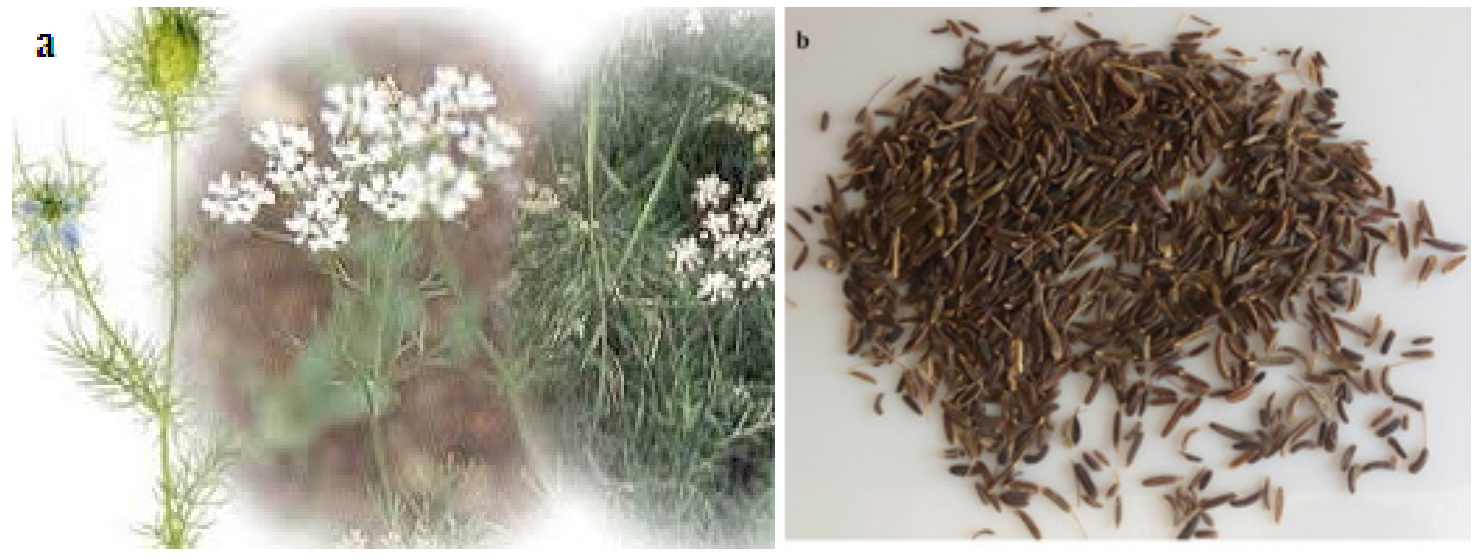

Fig. 1: Bunium persicum (Boiss.) B.Fedtsch plant (a) (Mandegari et al., 2012) and seeds (b). (Seeds were collected after flowers blooming and browning of seeds indicates maturation).

\section{MATERIAL AND METHODS}

A comprehensive literature review was conducted to provide an in-depth insight into the medicinal plant BP and its related subspecies. All relevant authentic scientific databases including Science Direct, Wiley-Blackwell, Springer, Google Scholar, Scopus, PubMed and Scientific Information Database were searched for the terms "Bunium persicum", "Cuminum cyminum", "Black zire"," black caraway", "Carum carvi", "Persian Cumin", "Zire kuhi”, " Shah zira “," Kala Zeera”, "Jira”, "Wild caraway" and "wild cumin" since last 20 years up to 10 November 2017. 6. Given to keywords, Totally 115 relative papers were obtained during 20 years period until Nov. 2017 which assessed the therapeutic effects of $B$. persicum and its application in the food industry.

\section{RESULT AND DISCUSSION}

\section{Phytochemistry}

Chemical compositions of the BP extract or essential oil are reported in several studies which have shown in Table 1. B. persicum essential oil (BPEO) or extract is recognized as a rich compound with a high amount of hydrocarbons and oxygenated monoterpenes in its composition (Ahmed, Soule et al., 2000). According to the GC-MS data, the major volatiles constituents remained similar in different varieties of a plant from different sites, but their relative quantities differed among plants from different regions. Cuminaldehyde, $\gamma$-Terpinene, limonene, Carvone, $\rho$-cymene, and $\beta$-Pinene are the main constituents in the chemical composition of BP. Many factors can affect the characteristics and chemical composition of the extracts or EOs of plants including genetic diversity, ecotypes of plants, varieties of plants, application of fertilizers, geographical location, environment, seasonal changes, stress during growth, maturation, drying and post-harvesting conditions. In addition, different parts of the aromatic plant, a method of extracting and chemical compositions of them can also be effective on their biological properties (Raut and Karuppayil, 2014).

\section{Other compounds}

$B$. persicum also contains other compounds belonging to different classes of natural products such as Caryophyllene, $\beta$-Pinene, Eugenol, carvacrol , Safrole , 1,8-Cineole, S-3-Carene, cuminyl acetate, pinocarvyl acetate, $\alpha$-methyl-benzene methanol, croweacin, Bornyl acetate, p-mentha-1,3-dien-7-al, p-mentha-1, 4-dien-7-al and p-menth-3-en-7-al, Sabinene, Myrcene, Caranone, $\alpha$-Thujene, Camphene and Terpinolene. (Chizzola et al., 2014; Shahsavari et al., 2008; Thappa et al., 1991).

\section{Therapeutic uses}

Several therapeutic effects have been reported in traditional medicine through the world including treatment of gastrointestinal disorders, urinary tract disorders and use as a diuretic, gynecologic, anticonvulsants, anti-helmentic, antiasthma and dyspnea (Boskabady and Moghaddas, 2004) (Table 2). Also, the seeds of this plant have antispasmodic, carminative, emmenagogue, expectorant, galactagogue, stimulant, stomachic and tonic properties and are useful in diarrhea and dyspepsia (de Carvalho and da Fonseca, 2006; Pourmortazavi et al., 2005).

Various studies showed that the aqueous extract and essential oil of caraway had anticonvulsant properties. This anticonvulsant activity may be due to the monoterpenic compounds present in the EOs (Mandegary et al., 2012). However, the essential oil was more potent and effective than the aqueous extract as an anticonvulsant. Additionally, the anticonvulsant effect of caraway 
was not due to a muscle relaxant activity. These findings support the acclaimed antiepileptic effect of caraway in folk medicine and propose its potential use in petit mal seizure in humans (Showraki et al., 2016). In another study to investigate the effects of essential oil and methanolic extracts of cumin as an anticonvulsant, the results showed that the essential oil of this plant is effective to control severe seizures in the body (Mandegary et al., 2012).
Diuretic and antifertility activities of this plant in rats have also been reported (Thakur et al., 2009). BPEO profoundly alters gastrointestinal smooth muscle contraction in a dose-dependent and tissue-specific manner (Jalilzadeh et al., 2011) Anti-ulcerative and anti-diarrheal properties of essential oil of this plant on rat have been reported by Jalilzadeh and colleges (Jalilzadeh et al., 2014; Jalilzadeh et al., 2014).

Table 1: The main components of different ecotypes of Bunium persicum (Boiss.) FEDTCH essential oil.

(a)

\begin{tabular}{|c|c|c|c|c|}
\hline Main components & $\begin{array}{c}\text { Part of plant } \\
\text { (Extract or EO) }\end{array}$ & Part of plant & Origins of plant & References \\
\hline $\begin{array}{c}\text { Cuminaldehyde }(27.8 \%), \gamma \text {-terpinene }(23 \%) \text {, c-Terpinen-7-al(19.2\%), } \\
\text { p-Cymene }(13.5 \%) \text {, limonene }(5.8 \%)\end{array}$ & $\mathrm{EO}$ & fruit & Iran & (Chizzola et al., 2014) \\
\hline $\begin{array}{c}\text { Carvone }(23.3 \%) \text {, limonene }(18.2 \%) \text {, germacrene D }(16.2 \%) \text {, } \\
\text { trans-dihydrocarvone }(14.0 \%) \text {, carvacrol }(6.7 \%)\end{array}$ & $\mathrm{EO}$ & fruit & Italy & (Iacobellis et al., 2005) \\
\hline $\begin{array}{c}\gamma \text {-terpinene }(46.1 \%) \text {, cuminaldehyde }(15 \%), \rho \text {-cymene }(6.7 \%) \text {, } \\
\text { limonene }(5.9 \%), \alpha \text {-Pinene }(2.7 \%)\end{array}$ & $\mathrm{EO}$ & seed & Kerman, Iran & (Kareshk et al., 2015) \\
\hline $\begin{array}{c}\text { Carvone }(78.8 \%) \text {, limonene }(10.1 \%) \text {, cis-limonene oxide }(1.8 \%) \text {, } \\
\text { trans-carveol }(1.3 \%) \text {, menthone }(1.2 \%)\end{array}$ & EO & fruit & Serbia & (Samojlik et al., 2010) \\
\hline $\begin{array}{c}\gamma \text {-terpinene }(44.2 \%) \text {, p-Cuminaldehyde }(16.9 \%), \gamma \text {-Terpinen-7-al }(10.5 \%) \\
\text { p-cymene }(8 \%) \text {, Bornyl acetate }(2.9 \%)\end{array}$ & EO & seed & Mashhad, Iran & (Oroojalian et al., 2010) \\
\hline $\begin{array}{c}\text { Cuminaldehyde }(11.4 \%), \gamma \text {-terpinene }(11.37 \%), \alpha \text {-Pinene }(11.27 \%) \text {, } \\
\alpha \text {-Terpinene }(11.13 \%), \text { S-3-Carene }(5.74 \%)\end{array}$ & $\mathrm{EO}$ & seed & Kerman, iran & (Ehsani et al., 2016) \\
\hline $\begin{array}{c}\text { Cuminaldehyde }(22.37 \%), \gamma \text {-terpinene }(19.36 \%), \gamma \text {-terpinene-7-al }(11.85 \%) \text {, } \\
\alpha \text {-terpinene }(7.3 \%), \rho \text {-cymene }(6.56 \%)\end{array}$ & EO & seed & Iran & (Rabiey et al., 2013) \\
\hline $\begin{array}{c}\text { Cuminaldehyde }(22.08 \%), \gamma \text {-terpinene }(17.86 \%), \gamma \text {-terpinene- } 7 \text {-al }(15.41 \%) \text {, } \\
\text { p-cymene }(7.99 \%), \beta \text {-Pinene }(4.68 \%)\end{array}$ & $\mathrm{EO}$ & seed & Iran & (Razzaghi-Abyaneh et al., 2009) \\
\hline $\begin{array}{l}\text { Cuminaldehyde }(23.04 \%), \gamma \text {-terpinene }(14.48 \%) \text {, } \\
\text { Trans-3-Caren-2-ol }(12.51 \%) \text {, Acetic acid, 3-cyclohex-1-enyl-1-methylprop- } \\
\text { 2-ynyl ester }(10.9 \%) \text {, Terpinolene }(8.27 \%)\end{array}$ & $\mathrm{EO}$ & seed & Iran & (Jalilzadeh et al., 2011) \\
\hline $\begin{array}{c}\gamma \text {-terpinene }(44.2 \%) \text {, cuminaldehyde }(16.9 \%), \rho \text {-cymene }(8 \%) \text {, Bornyl } \\
\text { acetate }(2.9 \%), 1,8 \text {-Cineole }(2.9 \%)\end{array}$ & EO & seed & Mashhad, Iran & (Jamshidi et al., 2014) \\
\hline $\begin{array}{c}\gamma \text {-terpinene }(21.86 \%) \text {, cuminaldehyde }(17.28 \%), \rho \text {-cymene }(6.21 \%), \\
\text { acetylphenylcarbinol }(5.83 \%), 1 \text {-limonene }(2.47 \%)\end{array}$ & EO & seed & Yazd, Iran & (Haghirogsa-dat et al., 2010) \\
\hline
\end{tabular}

(b)

\begin{tabular}{|c|c|c|c|c|}
\hline Main components & $\begin{array}{c}\text { Part of plant } \\
\text { (Extract or EO) }\end{array}$ & Part of plant & Origins of plant & References \\
\hline $\begin{array}{c}\text { Trans-anethole }(93.9 \%) \text {, limonene }(1.05 \%) \text { and estragole } \\
(1.05 \%) \text {, Linalool }(0.29 \%), 3 \text {-Carene }(0.15 \%)\end{array}$ & Ethanol/water, extract & Seed & India & (Padmashree et al., 2007) \\
\hline $\begin{array}{l}\gamma \text {-terpinene }(46.1 \%) \text {, cuminal (23.9\%), p-cymene }(15.9 \%) \text {, } \\
\text { limonene }(4.7 \%), 1,4 \text {-p-menthadien-7-al }(4.5 \%)\end{array}$ & $\begin{array}{l}\text { EO, hydroalcoholic and } \\
\text { polyphenolic extracts }\end{array}$ & Seed & Isfahan, Iran & (Hajhashemi et al., 2011) \\
\hline $\begin{array}{c}\gamma \text {-Terpinene }(14.4 \%), \text { Limonene }(4.42 \%), \mathrm{p} \text {-Cymene }(4.31 \%), \\
\beta \text {-Pinene }(2.94 \%), \alpha \text {-Pinene }(2.37 \%)\end{array}$ & Headspace vapor sample & Heads-pace & Iran & (Sekine et al., 2007) \\
\hline $\begin{array}{c}\Gamma \text {-Terpinene }(45.7 \%) \text {, Cuminaldehyde }(12.7 \%), \text { Limonene }(10.6 \%), \\
\text { Cuminyl alcohol }(6.4 \%) \text {, p-Cymene }(5.6 \%)\end{array}$ & $\begin{array}{l}\text { Supercritical fluid } \\
\text { extraction }\end{array}$ & seed & Mazandaran, Iran & (Pourmortaza-vi et al., 2005) \\
\hline $\begin{array}{c}\text { Cuminaldehyde }(22.34 \%) \text {, carvacrol }(19.88 \%) \text {, anisole }(15.19 \%) \text {, } \\
\text { o-Cymene }(12.04 \%), \gamma \text {-Terpinene }(9.77 \%), \alpha \text {-Propylbenzyl alcohol }(8.99 \%) \text {, } \\
\beta \text {-Pinene }(2.34 \%), \text { D-Limonene }(2.14 \%)\end{array}$ & $\mathrm{EO}$ & seed & Iran & (Aminzare et al., 2017) \\
\hline $\begin{array}{c}\gamma \text {-Terpinene }(46.1 \%) \text {, cuminaldehyde }(15.5 \%), \rho \text {-cymene }(6.7 \%), \\
\text { limonene }(5.9 \%), \beta \text {-Pinene }(2.5 \%)\end{array}$ & EO & seed & Kerman, Iran & (Sharififar et al., 2010) \\
\hline $\begin{array}{c}\text { Caryophyllene }(27.81 \%), \gamma \text {-terpinene }(15.19 \%) \text {, cuminyl acetate }(14.67 \%) \text {, } \\
\text { cuminaldehyde }(5.96 \%) \text {, p-cymene }(5.25 \%)\end{array}$ & EO & seed & Iran & (Shahsavari et al., 2008) \\
\hline $\begin{array}{c}\text { Limonene }(48.4 \%) \text {, carvone }(31.1 \%) \text {, apiole }(12.3 \%) \text {, Anethole }(2.7 \%) \text {, } \\
\text { cis-Dihydrocarvone }(2 \%)\end{array}$ & $\mathrm{EO}$ & seed & China & (Jiang et al., 2011) \\
\hline $\begin{array}{l}\text { Carvone }(46.62 \%) \text {, limonene }(45.49 \%) \text {, Safrole }(1.44 \%), \\
\text { cis-Dihydrocarvone }(1.01 \%) \text {, Eugenol }(0.66 \%)\end{array}$ & $\mathrm{EO}$ & fruits & Serbia & (Simic et al., 2008) \\
\hline $\begin{array}{c}\rho \text {-cymene }(25.7 \%), \gamma \text {-terpinene }(23.9 \%) \text {, cuminaldehyde }(22.6 \%) \text {, } \\
\text { p-Mentha-1'3-dien-7-al and p-Mentha-1,4-dien-7-al }(21.9 \%), \beta \text {-Pinene }(0.5 \%)\end{array}$ & $\mathrm{EO}$ & seed & india & (Thappa et al., 1991) \\
\hline
\end{tabular}


Table 2: Pharmacological and clinical studies of Bunium persicum (Boiss.) FEDTCH.

\begin{tabular}{|c|c|c|c|}
\hline Reported activity & Type of preparation & Main finding & References \\
\hline Diuretic activity & Aqueous extracts & The oral administration showed Diuretic activity in normal rats & (Lahlou et al., 2007) \\
\hline Antioxidant & EO & $\begin{array}{l}\text { Elevated antioxidant properties (Plasma) total antioxidants, conjugated diene, } \\
\text { lipid hydroperoxide and MDA content were diminished significantly by the } \\
\text { treatment of Boerhaavia diffusa and Black Caraway Oil in respect to the infected } \\
\text { group. In addition, daily use of dietary } B \text {. diffusa and Black Caraway oil will be } \\
\text { efficacious, cost-effective, no side effects and a good source of antihypercholes- } \\
\text { terolemic, hypolipidemic/antiatherogenicantioxidant actions and } \\
\text { anticarcinogenic. }\end{array}$ & (Khan et al., 2012) \\
\hline $\begin{array}{l}\text { Apoptotic activities } \\
\text { on human leukaemia } \\
\text { cell lines }\end{array}$ & Ethanol extract & C. carvi had no apoptotic effect on human leukemia cell lines. & (Bogucka-Kocka et al., 2008) \\
\hline Anti breast Cancer & $\begin{array}{l}\text { Thymoquinone, A Bioactive Com- } \\
\text { ponent of Black Caraway Seeds }\end{array}$ & $\begin{array}{l}\text { Thymoquinone could be useful in the management of Triple-negative breast } \\
\text { cancers, even when functional p53 is absent }\end{array}$ & (Sutton et al., 2014) \\
\hline $\begin{array}{l}\text { Bronchodilatory and } \\
\text { anticholinergic effects }\end{array}$ & $\begin{array}{l}\text { Aqueous extract, macerated } \\
\text { extract, EO }\end{array}$ & $\begin{array}{l}\text { It indicated that the bronchodilatory effect of Carum carvi is mainly due to the } \\
\text { non-competitive antagonistic property on muscarinic receptors and The } \\
\text { stimulatory effect and/or anti-histaminic effect of EO might be contributed to its } \\
\text { non-competitive property }\end{array}$ & (Boskabady and Talebi, 1999) \\
\hline $\begin{array}{l}\text { Antinociceptive and } \\
\text { anti-inflammatory }\end{array}$ & $\begin{array}{l}\text { EO, hydroalcoholic extract and } \\
\text { polyphenolic extract }\end{array}$ & $\begin{array}{l}\text { Results showed the analgesic and anti-inflammatory effects of the plant fruits } \\
\text { (IP injection in mice). }\end{array}$ & (Hajhashemi et al., 2011) \\
\hline $\begin{array}{l}\text { Effect on serum lipid } \\
\text { profile }\end{array}$ & Aqueous extract & $\begin{array}{l}\text { B. persicum extract administration is very useful in improvement of lipid profile } \\
\text { in hypercholesterolemic mice. }\end{array}$ & (Khaksari et al., 2014) \\
\hline Antihistaminic Effect & $\begin{array}{l}\text { Aqueous and macerated extracts, } \\
\text { EO }\end{array}$ & $\begin{array}{l}\text { Results indicated a competitive antagonistic effect of Bunium persicum at } \\
\text { histamine H1 receptors }\end{array}$ & $\begin{array}{l}\text { (Boskabady and Moghaddas, } \\
\text { 2004) }\end{array}$ \\
\hline Antinociceptive & $\mathrm{EO}$ & $\begin{array}{l}\text { Essential oil of } B \text {. persicum, administered i.p in mice (different dose), elicited } \\
\text { antinociceptive effects in a dose-dependent manner. BP induced analgesia may } \\
\text { be mediated via opioidergic and histamine } \mathrm{H} 1 \text { and } \mathrm{H} 2 \text { receptors. }\end{array}$ & (Zendehdel et al., 2015) \\
\hline Hypolipidemic effect & Aqueous extract & $\begin{array}{l}\text { Oral administration of Carum carvi decrease lipid levels in diet-induced } \\
\text { hyperlipidemic rats. }\end{array}$ & (Saghir et al., 2012) \\
\hline Anticonvulsant activity & EO, methanolic extract & $\begin{array}{l}\text { The essential oil of the plant might be useful to control absence and grand mal } \\
\text { seizures at dose } 1 \mathrm{~mL} / \mathrm{kg} \text { (treated i.p). This activity might be due to its content } \\
\text { of monoterpenes }\end{array}$ & (Mandegary et al., 2012) \\
\hline Antifertility & aqueous and ethanolic extract & $\begin{array}{l}\text { The blockage of the estrus phase induced by treatment (oral) of an aqueous and } \\
\text { ethanolic extract of both drug and showed a significant antifertility activity }\end{array}$ & (Thakur et al., 2009) \\
\hline Antidiabetic & $\mathrm{EO}$ & $\begin{array}{l}\text { Oral administration of black caraway oil significantly lower the serum creatinine } \\
\text { levels in the diabetic rats }\end{array}$ & (Ene et al., 2006) \\
\hline Antioxidant & $\mathrm{EO}$ & $\begin{array}{l}\text { The results showed that oral administration of caraway seed oil can be effective } \\
\text { in reducing oxidative stress in diabetes mellitus }\end{array}$ & (Erjaee et al., 2015) \\
\hline Effect on stomach ulcers & $\mathrm{EO}$ & $\begin{array}{l}\text { Dietary use od BPEO was safe and protected in doses of } 40 \text { and } 80 \mathrm{mg} / \mathrm{kg} \text { body } \\
\text { weight, which reduced the gastric ulcer and it was dose-dependent. }\end{array}$ & (Jalilzadeh et al., 2014) \\
\hline $\begin{array}{l}\text { Inhibitory Effect on } \\
\text { Castor-Oil Induced } \\
\text { Diarrhea }\end{array}$ & $\mathrm{EO}$ & $\begin{array}{l}\text { Results indicated that the plant may contain some biologically active constituents } \\
\text { that may reveal antimotility and antidiarrheal effects and support the popular } \\
\text { therapeutic use of } B \text {. persicum in traditional medicine for gastrointestinal } \\
\text { disorders }\end{array}$ & (Jalilzadeh et al., 2014) \\
\hline
\end{tabular}

\section{Antibacterial properties}

Plant-derived compounds especially essential oils (EOs) are well known as antibacterial agents due to their inhibitory properties against a wide range of pathogens, grampositive and gram-negative bacteria (Raut and Karuppayil, 2014). It is demonstrated that most antibacterial activity of these compounds is related to their phenolic composition (Ghasemlou et al., 2013). Making instability in the cell membrane is the main mechanism of action of these compounds. Due to the fact that EOs are lipophilic compounds, they can easily pass through the walls and membranes. Interactions between EO compounds with polysaccharides, fatty acids and phospholipids increase the permeability of the bacterial membrane and loss of ions and cellular content, resulting in cell death (Edris, 2007). Also, the effects on the activity of the proton pump, reduction of membrane clotting and leakage of cell contents can cause cells death (Di Pasqua et al., 2007; Oussalah et al., 2006). EOs can also cause them to die through denaturation of cytoplasmic proteins and inactivation of cellular enzymes (Gustafson, Liew et al., 1998; Burt 2004). 
Table 3: Summary of findings on the anti-bacterial effects of Bunium persicum (Boiss.).

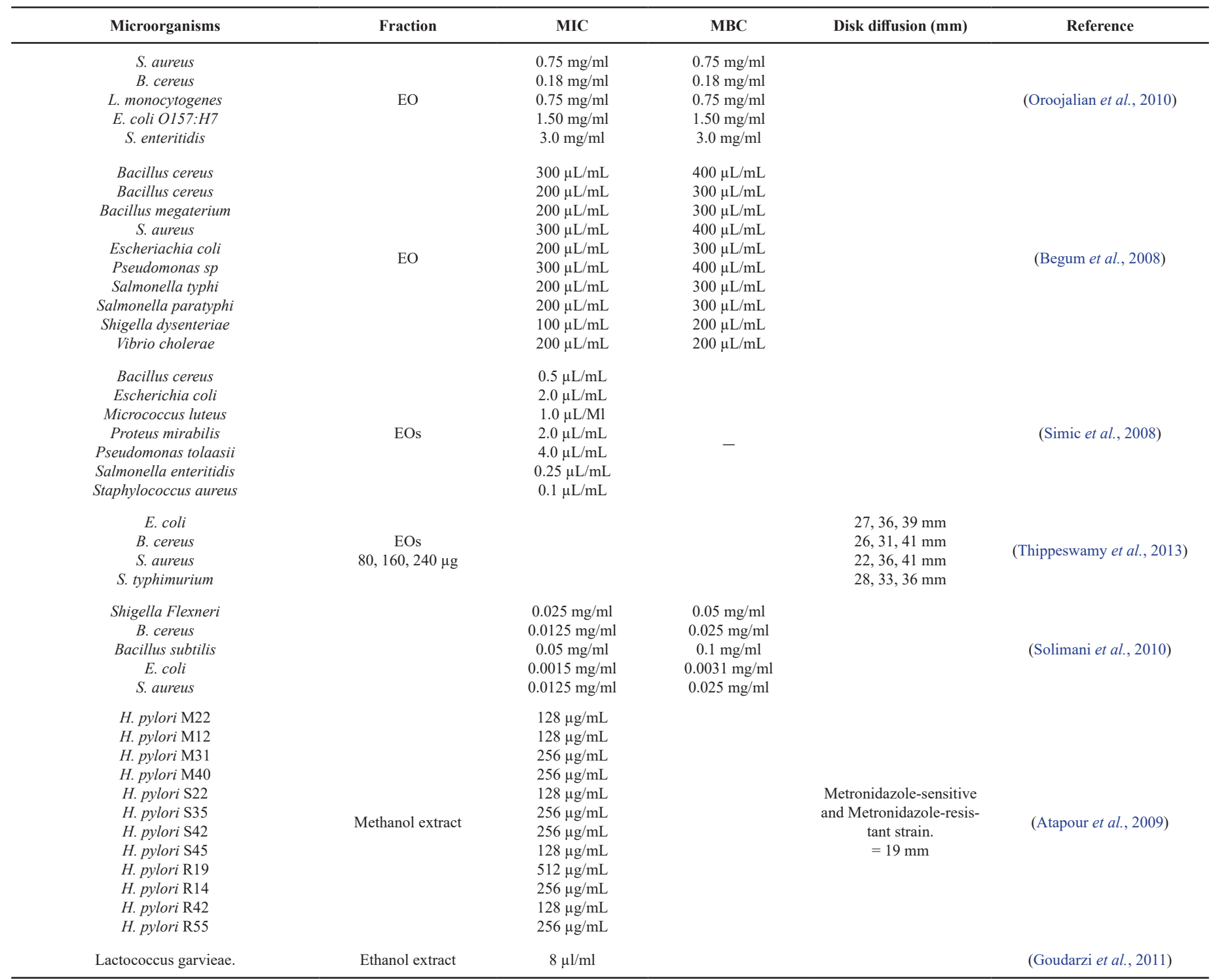

Several studies have shown the anti-microbial activity of BP EO and extract. Phenolic compounds have an antimicrobial activity such as carvacrol, thymol, $\gamma$-terpinene and $\rho$-cymene (Burt, 2004). The antibacterial effects of BP were studied on different strains of bacteria. Many studies showed that EO of BP has a greater inhibitory effect on grampositive bacteria than gram-negative bacteria (Oroojalian et al., 2010; Simic et al., 2008; Thippeswamy et al., 2013). The extract of this plant has a high antimicrobial effect on Escherichia coli (Gupta et al., 2011). Great inhibitory effects of BPEO on several pathogens such as Staphylococcus aureus (ATCC 25923, ATCC 6538), Bacillus cereus (ATCC 11778), Listeria monocytogenes (ATCC 19112, ATCC 19118, ATCC 7644), Escherichia coli O157: H7 (ATCC 43894), Salmonella spp. (ATCC 13311; ATCC 14028) has been reported (Abdalaziz et al., 2017; Ehsani et al., 2016; Fallahi et al., 2010; Ghderi et al., 2014; Jamshidi et al., 2014; Noori et al., 2014; Oroojalian et al., 2010; Rabiey et al., 2013). Findings of other related studies have been summarized in Table 3 .

\section{Anti-fungal properties}

Spices and herbs show antimicrobial and anti-fungal properties due to the ingredients in their essential oils. Antifungal effects of herbal essential oils have been evaluated in several studies. Cuminaldehyde is the main antifungal component among the compounds of derived EO of BP (Sekine et al., 2007). BPEO has shown significant anti-fungal properties against all types of food spoilage and pathogen fungi (Simic et al., 2008). In a study by Soliman and Badeaa (2002), the antifungal effect of BPEO on the growth of different species of pathogenic Aspergillus $(A$. flavus, A. parasiticus, and A. ochraceus) was studied and their obtained results indicated that this plant had significant inhibitory effects on growth and mycotoxin production of these fungi. Skrinjar et al. (2009) showed that different concentrations of EO have an inhibitory effect on A. fumigatus, A. flavus, and A. ochraceus species. Carum carvi EO also has significant inhibitory effects on Candida albicans growth (Skrobonja et al., 2013). In another study, it was showed that EO of $C$. carvi in addition to 
inhibiting $A$. parasiticus growth also effectively inhibits aflatoxin production by this mold (Razzaghi-Abyaneh et al., 2009). High concentration of BP extracts exhibited great antimicrobial activity against $A$. niger (Gupta et al., 2011).

\section{Antioxidative properties}

Many studies have been carried out in the field of antioxidant properties of extracts and essential oil of black Caraway which all indicated high antioxidant effects and scavenging ability of free radicals for this plant (Abdalaziz et al., 2017; Bamdad et al., 2006; Chizzola et al., 2014; Haghirogsadat et al., 2010; Samojlik et al., 2010). Essential oil and phenolic extract of black caraway show a good antioxidant and DPPH scavenging properties compared to BHT and BHA (Kapoor et al., 2010; Thippeswamy et al., 2013). Caraway has high antioxidant activity due to monoterpene alcohols, linalool, carvacrol, carvone, limonene, anethole, estragol, flavonoids and other polyphenolic compounds (Agrahari and Singh, 2014). It was reported that daily use of BP in diet will be efficacious, cost-effective as a good antioxidant with no side effects (Khan et al., 2012). The results of peroxide value (PV) and tiobarbituric acid (TBA) tests showed that BP could be used as a natural alternative instead of synthetic antioxidants (Zangiabadi et al., 2012). BP seed extract can prevent hemolysis of human erythrocytes that can be due to the presence of bioactive compounds which has a radical-scavenging activity (Atrooz, 2013). Caraway supplementation had a modulatory role in tissue lipid peroxidation, antioxidant profile and prevented 1,2-dimethylhydrazine-induced histopathological lesions in colon cancer of rats (Kamaleeswari and Nalini, 2006).

\section{Anticarcinogenic/Antimutagenic effects}

Colon cancer is one of the most common cancers around the world. It has been observed that diets containing cumin prevent colon cancer in rats and reduce the histopathologic lesions resulting from 1,2-dimethylhydrazine (DMH). It also reduces aberrant crypt foci expansion, the amount of fecal bile acid, neutral sterols and alkaline phosphatase activity (Deeptha et al., 2006; Kamaleeswari and Nalini, 2006). Monoterpenes like anethofuran, carvone and limonene which are present in the essential oil of the cumin have prominent anticarcinogenic properties (Agrahari and Singh, 2014). Compounds present in seed extract of caraway reversed 2,3,7,8-tetrachlorodibenzo-p-dioxin (TCDD) that induced mutagenicity. It inhibited TCDD induced CYP 1 A2 and CYP $1 \mathrm{~A} 1$ activities and expression in rat hepatoma cells in a dosedependent manner (Naderi-Kalali et al., 2005).

\section{Hypoglycemic and Hypolipidemic effects}

Seed extract of BP seems can cause insulin-dependent hypoglycemia. Hypoglycemic activity of these plants may result from inhibiting glucose production or stimulating the use of glucose in peripheral tissues especially in muscle and fat tissues (Eddouks et al., 2003). Extract of this herb can also act as inhibitors of glucose reabsorption in renal tubes (Maghrani et al., 2003). A survey on diabetic rats showed that ethanolic extract of BP seed in different concentrations decreased glucose and insulin levels significantly in diabetic rats, in compare with healthy rats (Eidi et al., 2010). Oral administration of cumin extract significantly reduced the glucose level of diabetic rats with no changes in plasma insulin concentrations which indicates that the mechanism of drug activity of this extract is independent with insulin secretion (Eddouks et al., 2004). Aqueous extract of Black zeera compounds, especially flavonoids and carvone have a strong antioxidant activity, which provides renoprotection against diabetes and its complications. Water extract of BP has shown protective effects on diabetes-induced renal damage in rats (Sadiq et al., 2010). Various studies on animals have shown that black Zeera has significant hypolipidemic effects (Khaksari et al., 2014; Saghir et al., 2012). Oral administration of C. carvi aqueous extract exhibits a potent lipid-lowering activity in diabetic and healthy rats (Lemhadri et al., 2006).

\section{Antiparasitic effects}

Some studies showed that the EO or extract of BP has antiparasitic effects. The evaluations show that BP may have significant antitoxoplasmosis effects. The results of a study on mice with acute toxoplasmosis showed that the oral administration of BP essential oil can be as a natural source to produce new prophylactic agent and use in toxoplasmosis (Kareshk et al., 2015). Findings of Mahmoudvand et al. (2016) demonstrated the potent scolicidal activity of BP with no significant toxicity, which might be used as a natural scolicidal agent in hydatid cyst surgery.

\section{Application in food systems}

Due to good antimicrobial and antioxidant properties, $\mathrm{BP}$ has a high potential for use in foods to prevent microbial and chemical degradation of food and as well as food-borne diseases. In this regard, several studies were conducted to increase foods shelf life. B. Persicum essential oil can be used not only as a natural flavor but also as a preservative against microbial contamination in foods such as Gouda cheese, and also plays an important role in consumer health (Taherkhani et al., 2015). The essential oil of this plant can be used as a natural preservative in the food industry due to the high antioxidant effect is shown in the starch film (Aminzare et al., 2017a). Also, biodegradable starchy films containing BPEO have a good inhibitory effect on food pathogens and can be used as an active ingredient in the food industry to enhance safety and to prolong foods' shelf life (Aminzare et al., 2017b). It was shown that addition of BP extract can have significant effects on the extending shelf life of fresh silver carp fish in refrigerated storage condition for 6-9 days (Eskandari et al., 2015). Also, in another study, it was shown that combination of BPEO, smoking, $\mathrm{NaCl}$ and low temperature as a Hurdle system has noticeable inhibition on L. monocytogenes growth in fish model systems (Rabiey et al., 2013). B. persicum essential oil has shown good inhibitory effects on food pathogens during the production, ripening, and storage of Iranian white Cheese, and also has shown a significant impact on the improvement of the color, odor, flavor, texture and general acceptability of this product (Ehsani et al., 2016). Addition of different concentrations of BP essential oil to chicken meat has shown the deterrent effect on the causative agents of chemical and microbial spoilage (Kamkar et al., 2017). Talebi et al. (2017) indicated that polylactic acid films containing BPEO may be useful for packaging of foods in order to increase their shelf life and safety. Studies in the field of maintenance and oxidative stability of various types of edible oils such as olive, Linseed and soybean oil have confirmed that BP essential oil can be used as 
food additive and a natural antioxidant compound to increase the shelf life and oxidative stability of oils (Keramat and Golmakani, 2016; Shahsavari et al., 2008; Zangiabadi et al., 2013).

\section{Toxicity}

Poisonous properties of essential oils and plant extracts were investigated in several studies. Due to the fact that BP is widely used in people's diet for its flavoring properties, there is no major concern about the toxic effects of this plant. Mandegary et al. (2012) assessed the toxicity of BP essential oil and extract on mice by Intaperitoneal (I.P) injection of essential oil (at doses of $0.75,1,1.25$ and $1.75 \mathrm{ml} / \mathrm{kg}$ ) and extract (at doses of 4 and $5 \mathrm{~g} / \mathrm{kg}$ ) and determined mortality and morbidity after 24 hours. Results showed that extract exhibited no mortality at a dose of $4 \mathrm{~g} / \mathrm{kg}$, but $16 \%$ mortality occurred at a dose of $5 \mathrm{~g} / \mathrm{kg}$ and the EO showed no mortality up to the dose of $2.5 \mathrm{ml} / \mathrm{kg}$. In another study, the toxicity of aqueous extract and essential oil of BP was investigated on rats by IP injection at different doses of aqueous extract $(1600,3200,3600,4000$ and $5000 \mathrm{mg} / \mathrm{kg})$ and essential oil $(200,400,600,800$ and $1200 \mathrm{mg} / \mathrm{kg}$ ). Maximum non-lethal concentrations of aqueous extract and EO were $3200 \mathrm{mg} / \mathrm{kg}$ and $400 \mathrm{mg} / \mathrm{kg}$, respectively (Showraki et al., 2016). An acute toxicity effect of BPEO was evaluated in another study on mice. The LD50 value of IP injection of the BPEO was $1.96 \mathrm{~mL} / \mathrm{kg}$ body weight, and the maximum nonfatal doses were $1.28 \mathrm{~mL} / \mathrm{kg}$ body wt. (Mahmoudvand et al., 2016).

\section{Future perspectives}

In traditional medicine, BP is used to treat gastrointestinal and urinary disorders, bloating and dyspepsia. Caraway mixture is used as a cumin formulation for the treatment of dyspepsia and bloating in children. According to researches, BP is a valuable drug that has antimicrobial, antioxidant, anti-inflammatory and lipid and glucose-lowering effects.

The most noticeable effects of BP herb are antimicrobial and antioxidant properties. Researches have shown that the essential oil of this plant has a good inhibitory effect on bacteria such as $S$. aureus, B. cereus, L. monocytogenes, E. coli, Salmonella and fungi such as Aspergillus and Candida. It seems that in the future, we will see the plant's extensive use in the food industry alone or in combination with other preserving agents and it can be used in food industry due to increased shelf-life of food and food safety. It was showed that BP and its derivatives (essential oil or extracts) alone or in combination with other food preservatives and or in composition of edible films or coating can be used to control spoilage and pathogens microorganisms as well as to prevent chemical spoilage in foods such as all types of oils, cheeses, fish, poultry and meat products. BP is widely used in people's diet due to its flavoring properties and there is no major concern about the toxic effects of this plant. However, the study on the acute and chronic toxicity of the compounds of this plant seems necessary for use as auxiliary treatment and application in food industry. Also, according to studies done on the anti-carcinogenic and anti-mutagenic properties of this plant, it seems that BP has the potential for use as an adjunct therapy in the treatment and prevention of seizure and cancer.

Given to the differences reported in the essential oil composition of this plant, it is recommended that future research is performed on the various effects and the role of each of its compounds and using a standard essential oil with specific compounds.

\section{CONFLICT OF INTEREST}

Authors declare there is no conflict of interest.

\section{REFERENCES}

Abdalaziz MN, Ali MM, Garbi MI, Dafalla MA, Kabbashi AS In-vitro Antimicrobial, Anti-oxidant Activities and Cytotoxicty of Carum carvi L. Am. J. Heterocycl. Chem, 2017; 3(3):23-27.

Agah S, Taleb AM, Moeini R, Gorji N, Nikbakht H. Cumin extract for symptom control in patients with irritable bowel syndrome: a case series. Middle East J. Dig. Dis, 2013; 5(4):217-222.

Agrahari P, Singh DK. "A review on the pharmacological aspects of Carum carvi." J. Biolog.Earth Sci, 2014; 4(1):1-13.

Ahmed R, Soule G, Demczuk WH, Clark C, Khakhria R, Ratnam S, Marshall S, Ng LK, Woodward DL, Johnson WM. "Epidemiologic typing of Salmonella enterica serotype Enteritidis in a Canada-wide outbreak of gastroenteritis due to contaminated cheese." J. Clin. Microbiol, 2000; 38(6):2403-2406.

Aminzare M, Amiri E, Abbasi Z, Hassanzadazar H, Hashemi M. "Evaluation of In vitro Antioxidant Characteristics of Corn Starch Bioactive Films Impregnated with Bunium persicum and Zataria multiflora Essential Oils.” Annu. Res. Rev. Biol, 2017a; 15(5):1-9.

Aminzare M, Hashemi M, Hassanzadazar H, Amiri E, Abbasi Z. "Antibacterial Activity of Corn Starch Films Incorporated with Zataria multiflora and Bonium persicum Essential Oils." Annu. Res. Rev. Biol, 2017b; 19(1):1-9.

Atapour M, Zahedi MJ, Mehrabani M, Safavi M, Keyvanfard V, Foroughi A, Siavoshi F, Foroumadi A. In vitro susceptibility of the Gramnegative bacterium Helicobacter pylori to extracts of Iranian medicinal plants. Pharm. Biol, 2009; 47(1):77-80.

Atrooz OM. The effects of Cuminum cyminum L. and Carum carvi $L$. seed extracts on human erythrocyte hemolysis. Int. J. Biol, 2013; 5(2):57-63.

Bamdad F, Kadivar M, Keramat J. Evaluation of phenolic content and antioxidant activity of Iranian caraway in comparison with clove and BHT using model systems and vegetable oil. Int.J. Food Sci. Technol, 2006; 41(s1):20-27.

Begum J, Bhuiyan MNI, Chowdhury JU, Hoque MN, Anwar MN. Antimicrobial activity of essential oil from seeds of Carum carvi and its composition. Bangladesh J. Microbiol, 2008; 25(2):85-89.

Bogucka-Kocka A, Smolarz H, Kocki J. Apoptotic activities of ethanol extracts from some Apiaceae on human leukaemia cell lines. Fitoterapia, 2008; 79(7):487-497.

Boskabady M, Talebi M. Bronchodilatory and anticholinergic effects of Carum carvi on isolated guinea pig tracheal chains. Med. J. Islam. Repub. Iran (MJIRI), 1999; 12(4):345-351.

Boskabady MH, Moghaddas A. Antihistaminic effect of Bunium persicum on Guinea Pig tracheal chains. Iran Biomed J, 2004; 8(3):149155.

Burt S. Essential oils: their antibacterial properties and potential applications in foods - a review. Int. J. Food Microbiol, 2004; 94(3):223253.

Chizzola R, Saeidnejad AH, Azizi M, Oroojalian F, Mardani H. Bunium persicum: variability in essential oil and antioxidants activity of fruits from different Iranian wild populations. Genet. Resour. Crop Evol, 2014; 61(8):1621-1631.

De Carvalho CC, Da Fonseca MMR. Carvone: Why and how should one bother to produce this terpene. Food Chem, 2006; 95(3):413422 .

Deeptha K, Kamaleeswari M, Sengottuvelan M, Nalini N. Dose dependent inhibitory effect of dietary caraway on 1,2-dimethylhydrazine induced colonic aberrant crypt foci and bacterial enzyme activity in rats Invest. New Drugs, 2006; 24(6):479-488. 
Di Pasqua R, Betts G, Hoskins N, Edwards M, Ercolini D, Mauriello G. Membrane toxicity of antimicrobial compounds from essential oils. J. Agric. Food Chem, 2007; 55(12):4863-4870.

Eddouks M, Jouad H, Maghrani M, Lemhadri A, Burcelin R. Inhibition of endogenous glucose production accounts for hypoglycemic effect of Spergularia purpurea in streptozotocin mice. Phytomedicine, 2003; 10(6-7):594-599.

Eddouks M, Lemhadri A, Michel JB. Caraway and caper: potential anti-hyperglycaemic plants in diabetic rats. J.Ethnopharmacol, 2004; 94(1):143-148..

Edris AE. Pharmaceutical and therapeutic potentials of essential oils and their individual volatile constituents: a review. Phytother. Res, 2007; 21(4):308-323.

Ehsani A, Hashemi M, Naghibi SS, Mohammadi S, Khalili Sadaghiani S. Properties of Bunium Persicum Essential Oil and its Application in Iranian White Cheese Against Listeria Monocytogenes and Escherichia Coli O157: H7. J. Food Saf, 2016; 36(4):563-570.

Eidi A, Eidi M, Haeri Rohani A, Basati F. Hypoglycemic effect of ethanolic extract of Carum carvi L. seeds in normal and streptozotocininduced diabetic rats. J. Med. Plant, 2010; 3(35):106-113.

Ene A, Bukbuk D, Ogunmola O. Effect of different doses of black caraway (Carum carvi L.) oil on the levels of serum creatinine in alloxan induced diabetic rats. J. Med. Sci, 2006; 6:701-703.

Ene A, Milala M, Nwankwo E. The effect of different doses of black caraway (Carum carvi L.) oil on the liver enzymes of alloxan-induced diabetic rats. J. Med. Sci, 2006; 6(6):994-998.

Erjaee H, Rajaian H, Nazifi S, Chahardahcherik M. The effect of caraway (Carum carvi L.) on the blood antioxidant enzymes and lipid peroxidation in streptozotocin-induced diabetic rats. Comp. Clin. Path, 2015; 24(5):1197-203.

Eskandari S, Hosseini H, Gholamzadeh M, Mousavi Khaneghah A, Hosseini E. The effects of black cumin, black caraway extracts and their combination on shelf life extension of silver carp (Hypophthalmichthys molitrix) during refrigerated storage. J. Food Saf, 2015; 35(2):154-160.

Fallahi J, Ebadi M, Moghaddam PR, Hedayati M, Tarighi S, editors. Evaluation of Six Medicinal Plant Essential Oil on Controlling Salmonella Pathogenic Bacteria in Comparison with Streptomycin. 6th Conference on Aromatic and Medicinal Plants of Southeast European Countries; 2010.

Ghasemlou M, Aliheidari N, Fahmi R, Shojaee-Aliabadi S, Keshavarz B, Cran MJ, Khaksar R. "Physical, mechanical and barrier properties of corn starch films incorporated with plant essential oils." Carbohydr. Polym, 2013; 98(1):1117-1126.

Ghderi P, Ahmadi R, Balkanyian F, Moridikyia A, Mahdavi E, Tavakoli P. In-vitro antibacterial activity of Bunium persicum and Mentha longifolia against Bacillus subtilis and Staphylococcus aureus. CAMS2014 Turkey.

Goudarzi M, Hamedi B, Malekpoor F, Abdizadeh R, Pirbalouti AG, Raissy M. Sensitivity of Lactococcus garvieae isolated from rainbow trout to some Iranian medicinal herbs. J. Med. Plants Res, 2011; 5(14):30673073.

Gupta A, Dubey M, Parmar M, Mahajan S, Sharma R. Evaluation of Antimicrobial activity of Carum carvi (seeds) extract against E. coli and Aspergillus niger. Drug Invention Today, 2011; 3(9):211-213.

Gustafson J, Liew Y, Chew S, Markham J, Bell H, Wyllie S, Warmington J. Effects of tea tree oil on Escherichia coli. Lett. Appl. Microbiol, 1998; 26(3):194-198.

Haghirogsadat F, Bernard F, Kalantar SM, Sheykhha MH, Hokmolahi F, Azimzade M, Hoori M. survey of effective compounds and antioxidant properties of essential oil of black cumin in Yazd province (In Persian). J. Shaheed Sadoughi Univ. Med. Sci, 2010; 18(4):284-291.
Hajhashemi V, Sajjadi SE, Zomorodkia M. Antinociceptive and anti-inflammatory activities of Bunium persicum essential oil, hydroalcoholic and polyphenolic extracts in animal models. Pharm. Biol, 2011; 49(2):146-151.

Iacobellis NS, Lo Cantore P, Capasso F, Senatore F. Antibacterial activity of Cuminum cyminum L. and Carum carvi L. essential oils. J. Agric. Food Chem, 2005; 53(1):57-61.

Jalilzadeh-Amin G, Maham M, Dalir-Naghadeh B, Kheiri F, editors. Effects of Bunium persicum (Boiss.) Essential oil on the contractile responses of smooth muscle (An In vitro Study). VRF, 2011; 2(2):87-96.

Jalilzadeh-Amin G, Nabizadeh H, Maham M. Inhibitory Effect of Bunium persicum Boiss Essential Oil on Castor-Oil Induced Diarrhea. J. Kerman Univ. Med. Sci, 2014; 21(2):139-150.

Jalilzadeh-Amin G, Yousefi A, Abdollahi-Pirbazari M. Anti ulcerogenic activity of Bunium percicum Boiss. essential oil in induced ulcer models in Wistar rats. J. Gorgan Univ. Med. Sci, 2014; 16(2):37-44.

Jamshidi A, Khanzadi S, Azizi M, Azizzadeh M, Hashemi M. Modeling the growth of Staphylococcus aureus as affected by black zira (Bunium persicum) essential oil, temperature, $\mathrm{pH}$ and inoculum levels. VRF, 2014; 5(2):107-114.

Jiang ZT, Sun ML, Li R, Wang Y. Essential oil composition of Chinese caraway (Carum carvi L.). J. ESSENT. OIL BEAR. PL, 2011; 14(3):379-382.

Kamaleeswari M, Deeptha K, Sengottuvelan M, Nalini N. Effect of dietary caraway (Carum carvi L.) on aberrant crypt foci development, fecal steroids, and intestinal alkaline phosphatase activities in 1,2-dimethylhydrazine-induced colon carcinogenesis. Toxicol. Appl. Pharmacol, 2006; 214(3):290-296.

Kamaleeswari M, Nalini N. Dose-response efficacy of caraway (Carum carvi L.) on tissue lipid peroxidation and antioxidant profile in rat colon carcinogenesis. J. Pharm. Pharmacol, 2006; 58(8):1121-1130.

Kamkar A, Khanjari A, Oladi M, Aghaee EM. Effect of packaging with chitosan film containing Bunium persicum L. essential oil on chemical and microbial properties of chicken fillet. J. Fasa Univ. Med. Sci, 2017; 7(1):104-115.

Kapoor IPS, Singh B, Singh G, De Heluani CS, De Lampasona MP, Catalan CA. Chemistry and antioxidant activity of essential oil and oleoresins of black caraway (Carum bulbocastanum) fruits: Part 69. J. Sci. Food Agr, 2010; 90(3):385-390.

Kareshk AT, Keyhani A, Mahmoudvand H, Oliaei RT, Asadi A, Andishmand M, Azzizian H, Babaei Z, Zia-Ali N. Efficacy of the Bunium persicum (Boiss) essential oil against acute toxoplasmosis in mice model. Iran. J. parasitol, 2015; 10(4):625-631.

Keramat M, Golmakani M. Effect of Thymus vulgaris and Bunium persicum essential oils on the oxidative stability of virgin olive oil. GRASAS ACEITES, 2016; 67(4):1-11.

Khaksari M, Ahmadi M, Najafipour H, Shahrokhi N. Effect of Bunium persicum aqueous extract plus endurance exercise on cardiorespiratory capacity and serum lipid profile. Avicenna J. Phytomed, 2014; 4(2):118-126.

Khan A, Thapliyal R, Chauhan S. Antioxidant Impacts of Boerhaavia diffusa \& Black caraway Oil on Conjugated Diene, Lipid Hydroperoxidation \& MDA Content in DMBA-Induced Hypercholesterolemia in Rats. Int. J. Pharm. Pharm. Sci, 2012; 4(3):600607.

Lahlou S, Tahraoui A, Israili Z, Lyoussi B. Diuretic activity of the aqueous extracts of Carum carvi and Tanacetum vulgare in normal rats. J. Ethnopharmacol, 2007; 110(3):458-463.

Lemhadri A, Hajji L, Michel J-B, Eddouks M. Cholesterol and triglycerides lowering activities of caraway fruits in normal and streptozotocin diabetic rats, 2006; 106(3):321-326.

Maghrani M, Lemhadri A, Jouad H, Michel J-B, Eddouks M. Effect of the desert plant Retama raetam on glycaemia in normal and streptozotocin-induced diabetic rats. J. Ethnopharmacol, 2003; 87(1):21-25.

Mahmoudvand H, Tavakoli Oliaei R, Mirbadie SR, Kheirandish F, Tavakoli Kareshk A, Ezatpour B Mahmoudvand H. Efficacy and safety 
of Bunium persicum [Boiss] to inactivate protoscoleces during hydatid cyst operations. Surg. Iinfect, 2016; 17(6):713-719.

Mandegary A, Arab-Nozari M, Ramiar H, Sharififar F. Anticonvulsant activity of the essential oil and methanolic extract of Bunium persicum (Boiss). B. Fedtsch. J. Ethnopharmacol, 2012; 140(2): 447-451.

Miraj S, Kiani S. Pharmacological activities of Carum carvi L. Pharm. Lett, 2016; 8(6):135-138.

Naderi-Kalali B, Allameh A, Rasaee M, Bach H-J, Behechti A, Doods K, et al. Suppressive effects of caraway (Carum carvi) extracts on 2,3,7,8-tetrachloro-dibenzo-p-dioxin-dependent gene expression of cytochrome P450 1A1 in the rat H4IIE cells. Toxicol. In vitro, 2005; 19(3):373-377.

Noori Z, Khanzadi S, Jamshidi A, Seifi HA. Modeling the effects of Bunium persicum (Black Zira) essential oil, $\mathrm{pH}$, inoculums size and temperature on the growth of Listeria monocytogenes. Iran. J. Vet. Res, 2014; 15(3):272-278.

Oroojalian F, Kasra-Kermanshahi R, Azizi M, Bassami MR. Phytochemical composition of the essential oils from three Apiaceae species and their antibacterial effects on food-borne pathogens. Food chem, 2010; 120(3):765-770.

Oussalah M, Caillet S, Lacroix M. Mechanism of action of Spanish oregano, Chinese cinnamon, and savory essential oils against cell membranes and walls of Escherichia coli O157: H7 and Listeria monocytogenes. J. Food prot, 2006; 69(5):1046-1055.

Padmashree A, Roopa N, Semwal A, Sharma G, Agathian G, Bawa A. Star-anise (Illicium verum) and black caraway (Carum nigrum) as natural antioxidants. Food chem, 2007; 104(1):59-66.

Pourmortazavi SM, Ghadiri M, Hajimirsadeghi SS. Supercritical fluid extraction of volatile components from Bunium persicum Boiss.(black cumin) and Mespilus germanica L.(medlar) seeds. J. Food Compos. Anal, 2005; 18(5):439-446.

Rabiey S, Hosseini H, Rezaei M. The hurdle effect of Bunium persicum essential oil, smoke and $\mathrm{NaCl}$ for controlling the Listeria monocytogenes growth in fish model systems. J. Food Saf, 2013; 33(2):13744.

Raut JS, Karuppayil SM. A status review on the medicinal properties of essential oils. Ind. Crops Prod, 2014; 62:250-264.

Razzaghi-Abyaneh M, Shams-Ghahfarokhi M, Rezaee M-B, Jaimand K, Alinezhad S, Saberi R, et al. Chemical composition and antiaflatoxigenic activity of Carum carvi L., Thymus vulgaris and Citrus aurantifolia essential oils. Food Control, 2009; 20(11):1018-1024.

Sadiq S, Nagi AH, Shahzad M, Zia A. The reno-protective effect of aqueous extract of Carum carvi [black zeera] seeds in streptozotocin induced diabetic nephropathy in rodents. Saudi J. Kidney Dis. Transpl, 2010; 21(6):1058-1065.

Saghir MR, Sadiq S, Nayak S, Tahir MU. Hypolipidemic effect of aqueous extract of Carum carvi (black Zeera) seeds in diet induced hyperlipidemic rats. Pak. J. Pharm. Sci, 2012; 25(2):333-337.

Salehi P, Mohammadi F, Asghari B. Seed essential oil analysis of Bunium persicum by hydrodistillation-headspace solvent microextraction. Chem. Nat. Compd, 2008; 44(1):111-113.

Samojlik I, Lakić N, Mimica-Dukić N, Đaković-Švajcer K, Božin B. Antioxidant and hepatoprotective potential of essential oils of coriander (Coriandrum sativum L.) and caraway (Carum carvi L.) (Apiaceae). J. Agr. Food Chem, 2010; 58(15):8848-8853.

Sekine T, Sugano M, Majid A, Fujii Y. Antifungal effects of volatile compounds from black zira (Bunium persicum) and other spices and herbs. J. Chem. Ecol, 2007; 33(11):2123-2132.

Shahsavari N, Barzegar M, Sahari MA, Naghdibadi H. Antioxidant activity and chemical characterization of essential oil of Bunium persicum. Plant Foods Hum. Nutr, 2008; 63(4):183-188.

Sharififar F, Yassa N, Mozaffarian V. Bioactivity of major components from the seeds of Bunium persicum (Boiss.) Fedtch. Pak. J. Pharm. Sci, 2010; 23(3):300-304.
Showraki A, Emamghoreishi M, Oftadegan S. Anticonvulsant effect of the aqueous extract and essential oil of Carum carvi L. Seeds in a Pentylenetetrazol model of seizure in mice. Iranian journal of medical sciences, 2016; 41(3):200-208.

Simic A, Rančic A, Sokovic M, Ristic M, Grujic-Jovanovic S, Vukojevic J, Marin P. Essential oil composition of Cymbopogon winterianus. and Carum carvi. and their antimicrobial activities. Pharm. Biol, 2008; 46(6):437-441.

Škrinjar MM, Mandić AI, Mišan AČ, Sakač MB, Šarić LĆ, Zec MM. Effect of Mint (Mentha piperita L.) and Caraway (Carum carvi $L$.) on the growth of some toxigenic Aspergillus species and Aflatoxin B1 production. ZB. MATITSE. SRP. PRIR. NAUKE, 2009; (116):131-139.

Skrobonja JM, Delić DN, Karaman MA, Matavulj MN, Bogavac MA. Antifungal properties of Foeniculum vulgare, Carum carvi and Eucalyptus sp. essential oils against Candida albicans strains. ZB. MATITSE. SRP. PRIR. NAUKE, 2013; (124):195-202.

Sofi PA, Zeerak NA, Singh P. Kala zeera (Bunium persicum Bioss.): a Kashmirian high value crop. Turkish J. Biol, 2009; 33(3):249258

Soliman K, Badeaa R. Effect of oil extracted from some medicinal plants on different mycotoxigenic fungi. Food Chem. Toxicol, 2002; 40(11):1669-1675.

Solimani N, Satari M, Seresht SS, Daneshmand S, Derkhshan S. Evaluation of drug interactions and antibacterial activity of essential oil of black caraway [Bunium persicum] against a number of gram-positive and negative bacteria (In Persian). Iran. J. Microbiol, 2010; 4(1):26-34 .

Sutton KM, Greenshields AL, Hoskin DW. Thymoquinone, a bioactive component of black caraway seeds, causes G1 phase cell cycle arrest and apoptosis in triple-negative breast cancer cells with mutant p53. Nutr. Cancer, 2014; 66(3):408-418.

Taherkhani P, Noori N, Akhondzadeh Basti A, Gandomi H, Alimohammadi M. Antimicrobial Effects of Kermanian Black Cumin (Bunium persicum Boiss.) Essential Oil in Gouda Cheese Matrix. J.Med. Plant, 2015; 2(54):76-85.

Talebi F, MIsaghi A, Khanjari A, Kamkar A, Gandomi H, Saeedi M. Evaluation of antimicrobial activity of Poly Lactic Acid (PLA) films containing cellulose nanoparticle and Bunium persicum and Mentha pepperita essential oils (EOs). Iran. J. Vet. Med, 2017; 11(4):289-298.

Thakur S, Bawara B, Dubey A, Nandini D, Chauhan NS, Saraf D. Effect of Carum carvi and Curcuma longa on hormonal and reproductive parameter of female rats. Int. J. Phytomed, 2009; 1(1):31-38.

Thappa R, Ghosh S, Agarwal S, Raina AK, Jamwal P. Comparative studies on the major volatiles of Kalazira (Bunium persicum seed) of wild and cultivated sources. Food chem, 1991; 41(2):129-134.

Thippeswamy N, Naidu KA, Achur RN. Antioxidant and antibacterial properties of phenolic extract from Carum carvi L. J.Pharm. Res, 2013; 7(4):352-357.

Zangiabadi M, Sahari MA, Barzegar M. Synergistic Effect of Zataria multiflora Boiss. and Bunium persicum (Boiss.) B. Fedtsch. Essential Oils on Linseed Oil Oxidative Stability. J.Med.Plant. By-prod, 2014, 2:177-185

Zangiabadi M, Sahari M, Barzegar M, Naghdi Badi H. Zataria multiflora and Bunium persicum essential oils as two natural antioxidants. J. Med. Plant, 2012; 1(41):8-21.

Zendehdel M, Torabi Z, Hassanpour S. Antinociceptive mechanisms of Bunium persicum essential oil in the mouse writhing test: role of opioidergic and histaminergic systems. Vet Med, 2015; 60(2):63-70.

How to cite this article:

Hassanzadazar H, Taami B, Aminzare M, Daneshamooz Sh. Bunium persicum (Boiss.) B. Fedtsch: An overview on Phytochemistry, Therapeutic uses and its application in the food industry. J App Pharm Sci, 2018; 8(10): 150-158. 